Review Article

\title{
Interfacial Reaction of Sn-Ag-Cu Lead-Free Solder Alloy on Cu: A Review
}

\author{
Liu Mei Lee and Ahmad Azmin Mohamad \\ School of Materials and Mineral Resources Engineering, Universiti Sains Malaysia, 14300 Nibong Tebal, Penang, Malaysia \\ Correspondence should be addressed to Ahmad Azmin Mohamad; azmin@eng.usm.my
}

Received 9 October 2012; Revised 18 January 2013; Accepted 4 February 2013

Academic Editor: J. Paulo Davim

Copyright ( 2013 L. M. Lee and A. A. Mohamad. This is an open access article distributed under the Creative Commons Attribution License, which permits unrestricted use, distribution, and reproduction in any medium, provided the original work is properly cited.

\begin{abstract}
This paper reviews the function and importance of $\mathrm{Sn}-\mathrm{Ag}$-Cu solder alloys in electronics industry and the interfacial reaction of $\mathrm{Sn}$ $\mathrm{Ag}-\mathrm{Cu} / \mathrm{Cu}$ solder joint at various solder forms and solder reflow conditions. The $\mathrm{Sn}-\mathrm{Ag}$-Cu solder alloys are examined in bulk and in thin film. It then examines the effect of soldering conditions to the formation of intermetallic compounds such as $\mathrm{Cu}$ substrate selection, structural phases, morphology evolution, the growth kinetics, temperature and time is also discussed. Sn-Ag-Cu leadfree solder alloys are the most promising candidate for the replacement of $\mathrm{Sn}-\mathrm{Pb}$ solders in modern microelectronic technology. $\mathrm{Sn}$-Ag-Cu solders could possibly be considered and adapted in miniaturization technologies. Therefore, this paper should be of great interest to a large selection of electronics interconnect materials, reliability, processes, and assembly community.
\end{abstract}

\section{Introduction}

Among various alloy systems that are considered as lead-free solder candidates, $\mathrm{Sn}-\mathrm{Ag}$-Cu alloys have been recognized as the most promising because of their relatively low melting temperature (compared with the $\mathrm{Sn}$-Ag binary eutectic leadfree solder), superior mechanical properties, and good compatibility with other components [1-3]. Sn-Ag-Cu alloys are widely used as lead-free solutions for ball-grid-array (BGA) interconnection in the microelectronic packaging industry as solder balls and pastes [4].

Among bumping materials, a family of solder alloys based on the ternary $\mathrm{Sn}-\mathrm{Ag}$ - $\mathrm{Cu}$ eutectic $\left(217^{\circ} \mathrm{C}\right)$ composition has the most potential for broad use in the industry [5]. The eutectic composition is favourable to be chosen because it behaves as an independent homogenous phase and has a unique metallographic structure and a distinct melting point [6]. Sn-Ag-Cu solders can promote enhanced joint strength as well as creep and thermal fatigue resistance and can permit increased operating temperatures for the fabrication of advanced electronic systems and devices [7, 8]. The International Printed Circuit Association has suggested that 96.5Sn-3.0Ag-0.5Cu (SAC305) and Sn-3.9Ag$0.6 \mathrm{Cu}$ (two near-eutectic alloys) will be the most widely used alloys in the future [7]. This prediction is attributed to their good mechanical properties, acceptable wetting properties, and suitable melting points $[2,3,9-11]$.

Lead-free solder joints have been reported to have fine and stable microstructures because of the formation of small-dispersed particles. Thus, these joints have higher shear strengths $[12,13]$. Sn-Ag-Cu solders require a higher reflow temperature because of its higher melting point. For instance, the melting point of $\mathrm{Sn}-3.8 \mathrm{Ag}-0.7 \mathrm{Cu}$ is $219^{\circ} \mathrm{C}$, and that of SAC305 is $217^{\circ} \mathrm{C}$. The high melting temperature not only requires a new reflow profile, but also increases the component stability concerns that accompany a higher temperature. Several components may not survive at a high reflow temperature.

\section{Lead-Free Solder and Its Applications}

Soldering is a well-recognized metallurgical joining method to bond solder to a base material (usually metal) at a melting point below $425^{\circ} \mathrm{C}$ [14]. Let us take Figure 1 as an example. During the soldering process, the SAC305 solder wire (Figure $1(\mathrm{a})$ ) melts and gets into contact with $\mathrm{Cu}$ substrate base metal (Figure 1(b)). Moreover, the Sn in the molten solder 


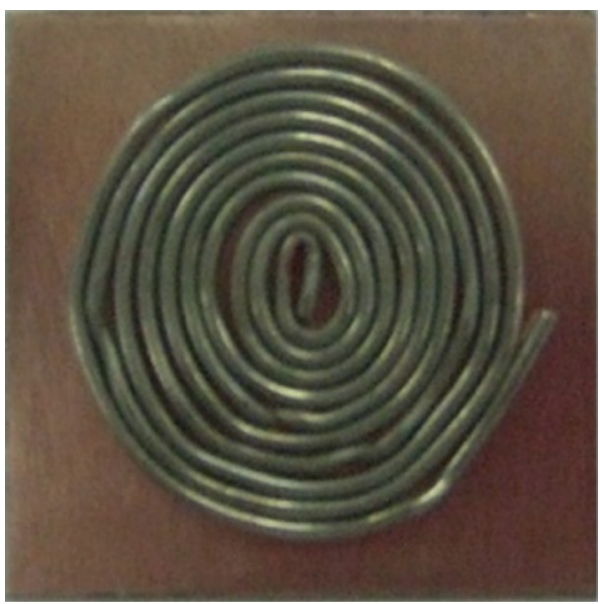

(a)

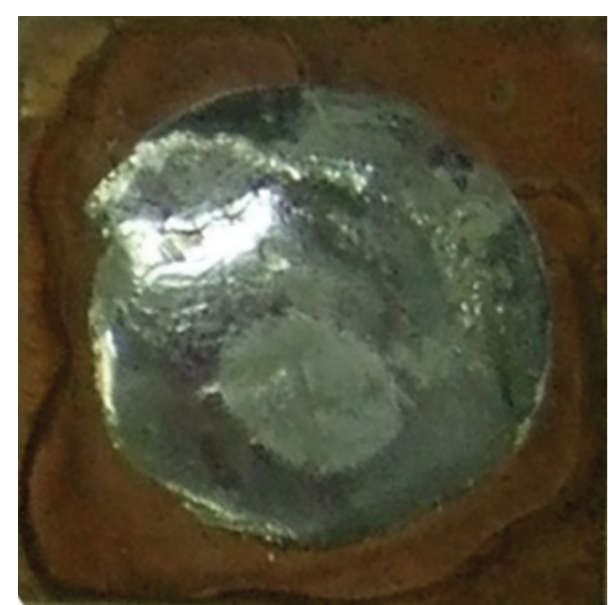

(b)

FIGURE 1: Appearance change of (a) a coiled SAC305 solder wire into (b) a solid SAC305 solder on the Cu substrate during solder reflowing.

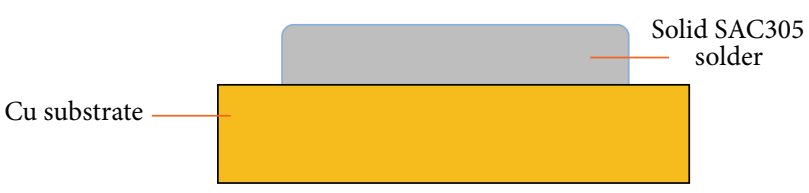

(a)
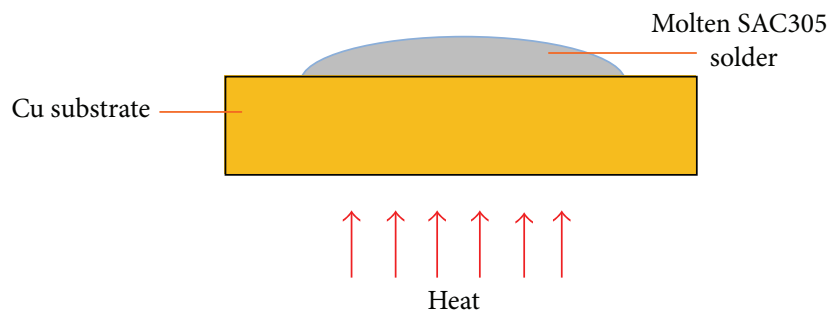

(b)

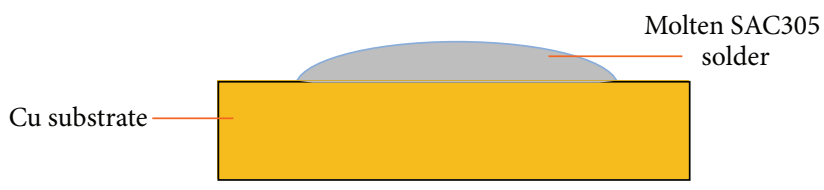

(c)

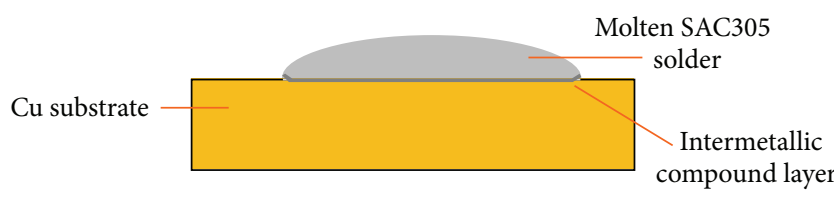

(d)

FIgURE 2: Solder wetting process: (a) SAC305 solder on the $\mathrm{Cu}$ substrate, (b) liquid solder spreading over the $\mathrm{Cu}$ substrate during soldering, (c) $\mathrm{Cu}$ diffuse in the liquid solder, and (d) Cu reacting with the liquid solder to form an intermetallic compound layer.

reacts with $\mathrm{Cu}$ to form intermetallic compound (IMC) on the interface. It is this IMC layer that bonds the solder and $\mathrm{Cu}$ together [15-20].
Generally, the soldering process is portrayed in Figure 2. The soldering process can be divided into three stages [21]:
(a) spreading;
(b) base metal dissolution;
(c) formation of an IMC layer.

The $\mathrm{Cu}$ substrate did not melt or change its microstructure during soldering. The liquid phase then transformed to various solid phases when the joints were cooled down. The different kinds and relative amounts of the solid phases formed during solidification are important for solder joint properties.

Solders are usually low melting point alloys because soldering is conducted when the solders are completely molten [22]. The products are used at their solid phases at relatively high operation temperatures. Hence, diffusivity is an important property for most solders. In addition, good wetting is required for good solders; thus, interfacial reactions with substrates are usually important not only at the liquid/solid contacts, but also at the solid/solid contacts at high operation temperatures [22].

The solder joint strength is controlled by the land pattern design and a good metallurgical bond between the component and the board. A reliable solder connection must have a solderable surface to form a good metallurgical bond between the solder and the components being joined. Interfacial reactions at the solder joints are key factors in the fabrication of electronic products.

\section{IMC of Sn-Ag-Cu Solders with Cu Substrate}

In electronic products, all common base materials, coatings, and metallizations, such as $\mathrm{Cu}, \mathrm{Ni}, \mathrm{Ag}, \mathrm{Ag}-\mathrm{Pd}$, and $\mathrm{Au}$, form IMCs with Sn. Therefore, chemical reactions occur between solders and conductor metals during soldering (i.e., component metallizations, board surface finishes, and underlying conductors), and IMCs nucleate and grow at the solder/conductor interfaces. 


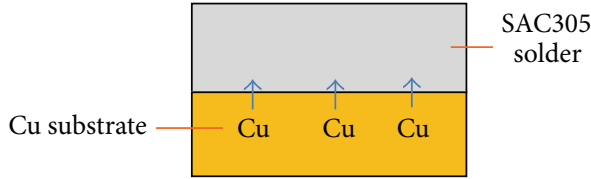

(a)

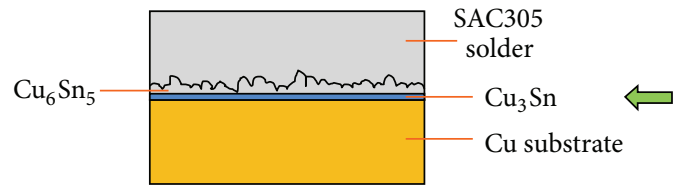

(d)

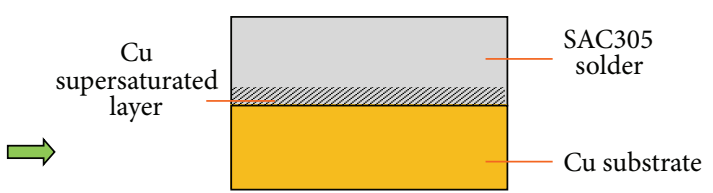

(b)
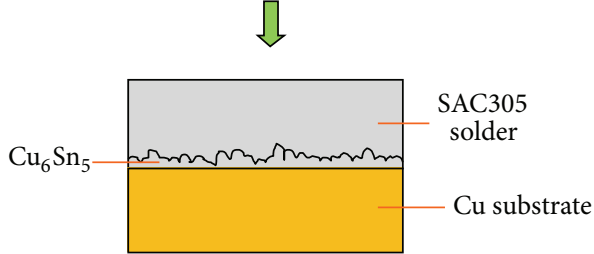

(c)

FIGURE 3: Scheme of the interfacial reaction of SAC305/Cu during solder reflow: (a) dissolution of the Cu substrate, (b) supersaturation of

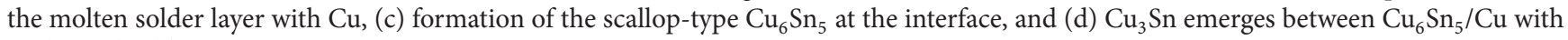
prolonged soldering.

The presence of IMCs between solders and conductor metals is desirable because it results in good metallurgical bonding. A thin, continuous, and uniform IMC layer is an essential requirement for good bonding. Without IMCs, the solder/conductor joint is weak because no metallurgical interaction occurs in the bonding, which is disastrous to electronic packaging. However, a thick IMC layer at the solder/conductor metal interface may degrade the reliability of the solder joints because of their inherent brittle nature and their tendency to generate structural defects caused by mismatches of the physical properties (such as elastic modulus and coefficient of thermal expansion) [23]. A thick IMC layer should be avoided during the process. Thus, knowledge of the solder/conductor metal interactions and phase evolution in the solder interconnections is important to understand the reliability of solder interconnections from a metallurgical viewpoint and to optimize the soldering process [17].

The intermetallic reaction layers are formed in three consecutive stages [17]:
(a) dissolution;
(b) chemical reaction;
(c) solidification.

During the soldering of the $\mathrm{Sn}-\mathrm{Ag}-\mathrm{Cu}$ solder on the $\mathrm{Cu}$ substrate, the $\mathrm{Cu}$ starts to dissolve instantaneously to the molten solder after the flux removed the oxides and permitted metallurgical contact between the solder and contacted $\mathrm{Cu}$. The initial rate of dissolution is very high. The dissolution is a nonequilibrium process, and a very high concentration of $\mathrm{Cu}$ could be locally found in the $\mathrm{Cu} /$ liquid interface. After a short duration of time, the layer of molten solder adjacent to the contacted $\mathrm{Cu}$ becomes supersaturated with the dissolved $\mathrm{Cu}$ throughout the interface.

From a thermodynamics viewpoint, the solid IMC starts to form in the layer of the solder adjacent to the contacted metal at the local equilibrium solubility. $\mathrm{Cu}_{6} \mathrm{Sn}_{5}$ crystallites are formed because a large driving force for the chemical reaction between $\mathrm{Cu}$ and $\mathrm{Sn}$ atoms exists at the metastable composition. Scallop-type $\mathrm{Cu}_{6} \mathrm{Sn}_{5}$ first formed at the $\mathrm{Sn} / \mathrm{Cu}$ interface during soldering, and its rate of formation is very fast. $\mathrm{Cu}_{6} \mathrm{Sn}_{5}$ was formed by the dissolution of $\mathrm{Cu}$, followed by a chemical reaction. If contact with the molten solder is long enough, $\mathrm{Cu}_{3} \mathrm{Sn}$ formed between $\mathrm{Cu}_{6} \mathrm{Sn}_{5}$ and $\mathrm{Cu}$. $\mathrm{Cu}_{3} \mathrm{Sn}$ was formed by diffusion and by reaction type growth [24].

Figure 3 briefly illustrates the interfacial reaction of SAC305/Cu during solder reflow. When heat is applied, the solid SAC305 solder melts, and the contacted Cu substrate starts to dissolve to the molten SAC305 solder (Figure 3(a)). The layer of molten SAC305 solder near the SAC305/Cu interface becomes supersaturated with the dissolved $\mathrm{Cu}$ (Figure 3(b)). The solid IMC begins to form at the interfacial zone. $\mathrm{Cu}_{6} \mathrm{Sn}_{5}$ with a scallop structure was first formed (Figure 3(c)), followed by thin layer-like $\mathrm{Cu}_{3} \mathrm{Sn}$ (Figure 3(d)).

\section{Structural Phases of IMCs in $\mathrm{Sn}-\mathrm{Ag}-\mathrm{Cu} / \mathrm{Cu}$}

$\mathrm{Cu}$ is the most frequently used conductor metal, and it is utilized in contact with solders because of its good solderability characteristic and excellent thermal conductivity performance [25]. Liu et al. [26] investigated the interfacial reactions between a SAC305 solder paste and a polycrystalline $\mathrm{Cu}$ substrate at $250^{\circ} \mathrm{C}$ and $300^{\circ} \mathrm{C}$ from $30 \mathrm{~s}$ to $1800 \mathrm{~s}$. They found that some nanosized $\mathrm{Ag}_{3} \mathrm{Sn}$ particles were adsorbed on the SAC305/Cu interface after soldering. The authors explained that $\mathrm{Ag}$ atoms first reacted with $\mathrm{Sn}$ to form an $\mathrm{Ag}_{3} \mathrm{Sn}$ phase in the liquid solder. During solidification, the $\mathrm{Ag}_{3} \mathrm{Sn}$ phase precipitated near the IMCs and was prone to be "captured" by the IMCs. Moreover, Wang et al. [27] performed Xray diffraction (XRD) analysis on interfacial SAC305/Cu to examine the phase structure of IMC during soldering at $260^{\circ} \mathrm{C}$ for $20 \mathrm{~s}$. The XRD pattern indicates that the crystal structure of IMCs for $\mathrm{SAC} 305 / \mathrm{Cu}$ is $\mathrm{Cu}_{6} \mathrm{Sn}_{5}$. However, no $\mathrm{Ag}_{3} \mathrm{Sn}$ phase was detected in this case.

The XRD patterns of SAC305 in various solder forms are shown in Figure 4. The overall intensity of the SAC305 solder wire was much lower than that of the as-deposited 


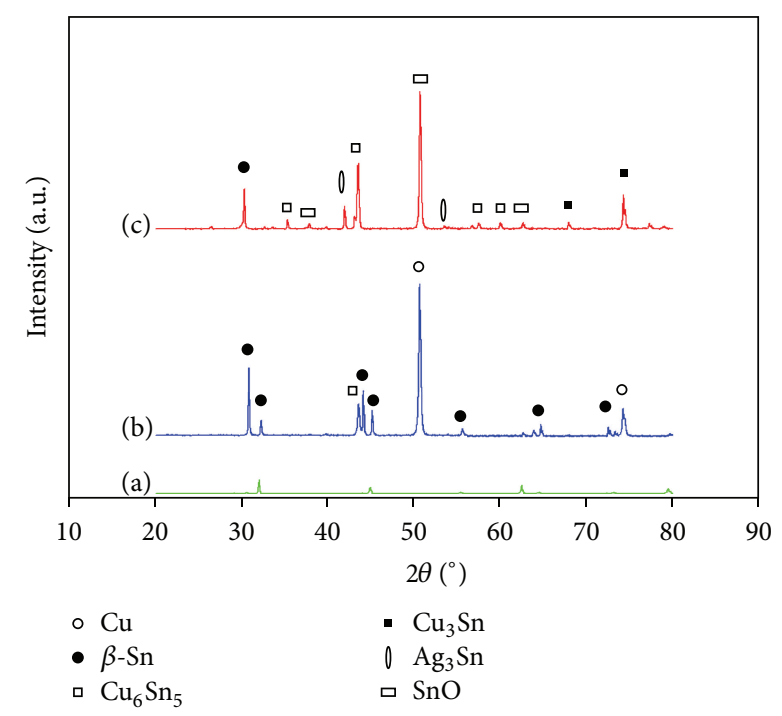

FIGURE 4: XRD patterns from the top surface of (a) SAC305 solder wire, (b) as-deposited SAC305 thin film, and (c) as-reflowed $\mathrm{SAC} 305 / \mathrm{Cu}$.

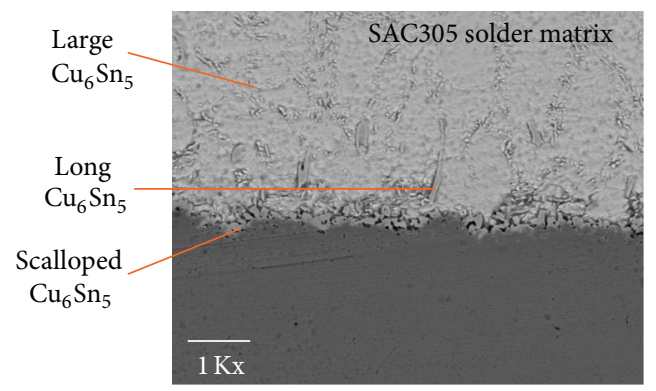

Figure 5: FESEM image of SAC305 solder joints with the $\mathrm{Cu}$ substrate.

SAC305 thin film and of the as-reflowed SAC305/Cu. The asdeposited SAC305 thin film exhibited $\beta$-Sn, $\dot{\eta}-\mathrm{Cu}_{6} \mathrm{Sn}_{5}$, and $\mathrm{Ag}_{3} \mathrm{Sn}$ reflections. Heating the SAC305 solder wire did not result in phase changes, except in its relative intensity. The peaks of $\mathrm{Cu}_{6} \mathrm{Sn}_{5}$ and $\mathrm{Ag}_{3} \mathrm{Sn}$ were too low to be seen in the XRD pattern of the SAC305 solder wire (Figure 4(a)), which had lower intensity than that of the as-deposited SAC305 thin film (Figure 4(b)). After solder reflow at $230^{\circ} \mathrm{C}$, most $\beta$-Sn phases diminished (Figure 4(c)). By contrast, the diffraction peaks of $\dot{\eta}-\mathrm{Cu}_{6} \mathrm{Sn}_{5}$ and $\mathrm{Ag}_{3} \mathrm{Sn}$ became more evident. New phases of IMCs formed and were confirmed as $\eta-\mathrm{Cu}_{6} \mathrm{Sn}_{5}, \mathcal{E}$ $\mathrm{Cu}_{3} \mathrm{Sn}$, and $\mathrm{SnO}$.

\section{Microstructure Evolution of IMCs in $\mathrm{Sn}-\mathbf{A g}-\mathbf{C u} / \mathbf{C u}$}

Kar et al. [28] evaluated the microstructure of a transition joint consisting of an $\mathrm{Sn}-\mathrm{Ag}-\mathrm{Cu}$ solder alloy and a $\mathrm{Cu}$ substrate in a reflowed condition at $230^{\circ} \mathrm{C}$ for $120 \mathrm{~s}$. They confirmed the presence of $\mathrm{Cu}_{6} \mathrm{Sn}_{5}, \mathrm{Cu}_{3} \mathrm{Sn}$, and $\mathrm{Ag}_{3} \mathrm{Sn}$ intermetallic phases at the interfacial reaction layer (IRL). The presence of Ag in the IRL was minimal and did not take part in the formation of IMCs at the interface. Gao et al. [29] assumed that a significant quantity of Ag was entangled with $\mathrm{Sn}$ to form $\mathrm{Ag}_{3} \mathrm{Sn}$ within the solder alloy. Thus, the extent of diffusion of Sn towards the IRL was reduced.

One of the characteristics of IMC is the formation of a scallop-type morphology. Scallop-type $\mathrm{Cu}_{6} \mathrm{Sn}_{5}$ IMCs were formed at SAC305/Cu interfaces, whereas the solder was in the molten state during the reflow at $270^{\circ} \mathrm{C}$ for $120 \mathrm{~s}$ [30]. This result also corresponds to the study done by Kim et al. [1] on the effect of IMC on a SAC305 solder alloy (in the form of pastes and balls) with a $\mathrm{Cu}$ substrate joint after reflow treatment at $260^{\circ} \mathrm{C}$. Yoon and Jung [31] also investigated the interfacial reaction of $\mathrm{Cu} / \mathrm{Sn}-3.5 \mathrm{Ag}-0.7 \mathrm{Cu} / \mathrm{Cu}$ sandwich solder joints. Typical scallop-type $\mathrm{Cu}_{6} \mathrm{Sn}_{5}$ IMC layers were formed at both $\mathrm{Sn}-3.5 \mathrm{Ag}-0.7 \mathrm{Cu} / \mathrm{Cu}$ interfaces after reflow. The layers had a composition of approximately 54.8 at.\% $\mathrm{Cu}$ and 45.2 at.\% Sn.

Figure 5 displays the cross-sectional FESEM micrograph of the as-reflowed SAC305/Cu sample. The reaction layer on the $\mathrm{Cu}$ substrate is the scallop $\mathrm{Cu}_{6} \mathrm{Sn}_{5}$ phase, which was formed during the reflow treatment. Long $\mathrm{Cu}_{6} \mathrm{Sn}_{5}$ IMCs were observed at the top of the interfacial $\mathrm{Cu}_{6} \mathrm{Sn}_{5}$ scallops, and the growth is attributed to the $\mathrm{Cu}$ flux from the $\mathrm{Cu}$ substrate to the scallops [32]. However, relatively large $\mathrm{Cu}_{6} \mathrm{Sn}_{5}$ IMCs were formed in the solder matrix because of the dissolution of the $\mathrm{Cu}$ pad. Some $\mathrm{Cu}$ pads were dissolved in the molten SAC305 solder during reflow, and the dissolved $\mathrm{Cu}$ was precipitated as large $\mathrm{Cu}_{6} \mathrm{Sn}_{5}$ IMCs in the solder matrix. In other words, the solidification of a eutectic SAC305 solder produced a mixture of $\beta$-Sn matrix, fine $\mathrm{Ag}_{3} \mathrm{Sn}$, and $\mathrm{Cu}_{6} \mathrm{Sn}_{5}$ IMC particles.

Moreover, $\mathrm{Ag}_{3} \mathrm{Sn}$ IMC was uniformly dispersed in the solder after reflow [33]. A microstructural analysis on Sn-Ag$\mathrm{Cu}$ solder alloys with different $\mathrm{Ag}$ contents was performed to understand the microstructure details and to evaluate the formation of intermetallic compounds. Elongated plates of the $\varepsilon-\mathrm{Ag}_{3} \mathrm{Sn}$ phase were observed in the eutectic matrix of Sn-1.0Ag-0.5Cu (SAC105), Sn-2.0Ag-0.5Cu (SAC205), and SAC305 solder alloys. On the other hand, large $\varepsilon-\mathrm{Ag}_{3} \mathrm{Sn}$ intermetallics plates and elongated plates of the $\varepsilon-\mathrm{Ag}_{3} \mathrm{Sn}$ phase were clearly seen in the $\mathrm{Sn}-4.0 \mathrm{Ag}-0.5 \mathrm{Cu}$ (SAC405) solder alloy. Figure 6 illustrates the morphologies of $\mathrm{Ag}_{3} \mathrm{Sn}$ IMCs in the solder matrix, which can be changed by varying the $\mathrm{Ag}$ content. $\mathrm{Ag}_{3} \mathrm{Sn}$ IMCs of elongated plate-like structure exist when the Ag content is between 1.0 and $3.0 \mathrm{wt} \%$ (Figure 6(a)). A higher Ag composition of $4.0 \mathrm{wt} \%$ results in the formation of large $\mathrm{Ag}_{3} \mathrm{Sn}$ IMCs, as in Figure 6(b).

The overall reliability can be greatly affected by the amount and size of $\varepsilon-\mathrm{Ag}_{3} \mathrm{Sn}$ IMCs in the microstructure. Large $\varepsilon-\mathrm{Ag}_{3} \mathrm{Sn}$ IMCs are generally believed to be detrimental in both crack initiation and propagation, and numerous studies have attributed the failure of SAC305 solders to large plate-like $\varepsilon-\mathrm{Ag}_{3} \mathrm{Sn}$ IMCs under impact and thermal cycling stimuli $[1,34,35]$. In addition, the formation of large platelike $\varepsilon-\mathrm{Ag}_{3} \mathrm{Sn}$ IMCs causes solid dissolution and precipitation hardening, which in turn decreases the matrix strength [36, 37].

Figure 7 shows the interfacial reaction of the SAC305 thin film deposited by the thermal evaporation technique. The thin film was subsequently reflowed at $230^{\circ} \mathrm{C}$ for $30 \mathrm{~s}$. The 


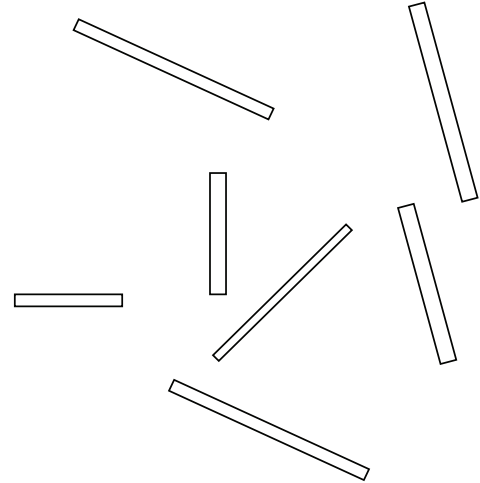

(a)

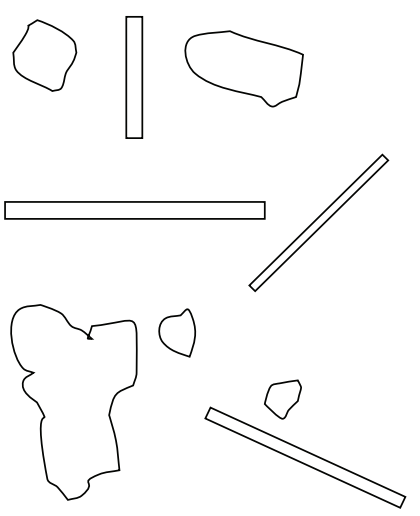

(b)

Figure 6: Morphologies of $\mathrm{Ag}_{3} \mathrm{Sn}$ compound at varying Ag concentrations with (a) 1.0 Ag to 3.0 Ag alloying and (b) $4.0 \mathrm{Ag}$ alloying.

top white layer is the SAC305 solid layer, which comprised loose SAC305 particles that were physically adsorbed on the $\mathrm{Cu}$ substrate (Figure 7(a)). After solder reflow, interfacial reaction occurred. As shown in Figure $7(\mathrm{~b})$, two layers of IMCs were formed. The top region is $\mathrm{Cu}_{6} \mathrm{Sn}_{5}$, and the layer beneath is $\mathrm{Cu}_{3} \mathrm{Sn}$. $\mathrm{Cu}_{6} \mathrm{Sn}_{5}$ was thick and irregular in thickness, whereas $\mathrm{Cu}_{3} \mathrm{Sn}$ was very thin and had a more uniform thickness and a layer-like morphology. However, the thin layer followed the topography of the adjacent $\mathrm{Cu}_{6} \mathrm{Sn}_{5}$ phase layer to a particular extent. No spalling or flaking of the IMCs was observed, which indicates that the Sn concentration in the thin film was low. The thin film SAC305 solder completely reacted with excess $\mathrm{Cu}$ substrate to form $\mathrm{Cu}_{6} \mathrm{Sn}_{5}$ during reflow. The $\mathrm{Cu}_{3} \mathrm{Sn}$ intermetallic layer consistently increased with increasing temperature, whereas $\mathrm{Cu}_{6} \mathrm{Sn}_{5}$ gradually decreased with increasing reflow temperatures.

\section{Formation and Growth Kinetics of Interfacial IMCs}

The formation of scallop $\mathrm{Cu}_{6} \mathrm{Sn}_{5}$ has been observed in wetting reactions between eutectic $\mathrm{Sn}-\mathrm{Pb}$ and $\mathrm{Cu}$ [38-40], eutectic Sn-Ag and $\mathrm{Cu}$ [39], and eutectic Sn-Bi and $\mathrm{Cu}$ [39]. The scallop is a common growth mode, which grows bigger but fewer with time. This behavior indicates that a nonconservative ripening reaction occurs among scalloptype grains. Furthermore, the scallop-type morphology is stable as long as unreacted $\mathrm{Cu}$ is present.

In a $\mathrm{Cu}-\mathrm{Sn}$ system, $\mathrm{Cu}_{6} \mathrm{Sn}_{5}$ and $\mathrm{Cu}_{3} \mathrm{Sn}$ IMCs form at solder/substrate interfaces [1, 39, 41-47]. The actual formation sequence of these phases is determined by local thermodynamic conditions at the $\mathrm{Cu} / \mathrm{Sn}$ interface. The $\mathrm{Cu}_{6} \mathrm{Sn}_{5}$ phase precipitates during the earliest stages of solder/substrate interactions, which correspond to a higher driving force for precipitation than that of the $\mathrm{Cu}_{3} \mathrm{Sn}$ phase $[48,49]$. The $\mathrm{Cu}_{6} \mathrm{Sn}_{5}$ phase has been experimentally confirmed to precipitate in a random fashion along the solder/substrate interface.

The formation and growth of interfacial Cu-Sn IMCs is illustrated in Figure 8. During the initial stage (Figure 8(a)), individual $\mathrm{Cu}_{6} \mathrm{Sn}_{5}$ grains appear at random locations along the solid/liquid interface within a few milliseconds. After the $\mathrm{Cu}_{6} \mathrm{Sn}_{5}$ grains appear, they began to spread along the interface without much growth perpendicular to the solder/substrate interface until they encounter other spreading grains, which resulted in the formation of a relatively uniform IMC layer of $\mathrm{Cu}_{6} \mathrm{Sn}_{5}$ (Figure 8(b)).

After the initial formation of the IMC layer, its thickness grows at the expense of the underlying substrate. The individual grains acquire a scallop-like morphology [50] that continues to grow perpendicularly to the interface (Figure 8(c)). The ripening process contributes to the formation of the scallop structure of IMCs, which result in the coarsening of the scallops as its number is decreasing (Figure $8(d)$ ). This reaction is driven by the Gibbs-Thomson effect in the ripening process. Thus, smaller IMC grains are dissolved in the liquid solder, and the growth of neighboring grains is further promoted $[39,51,52]$.

After the precipitation of the $\mathrm{Cu}_{6} \mathrm{Sn}_{5}$ phase, the precipitation of the $\mathrm{Cu}_{3} \mathrm{Sn}$ phase at the $\mathrm{Cu}_{6} \mathrm{Sn}_{5}$ /substrate interface becomes thermodynamically possible. This phenomenon is usually observed during the later stages of the soldering reactions. The thickness of $\mathrm{Cu}_{3} \mathrm{Sn}$ is expected to be much smaller than that of $\mathrm{Cu}_{6} \mathrm{Sn}_{5}$ because $\mathrm{Cu}_{3} \mathrm{Sn}$ was grown by solid state diffusion.

The evolution of $\mathrm{Cu}-\mathrm{Sn}$ IMCs for $\mathrm{Sn}-\mathrm{Ag}-\mathrm{Cu} / \mathrm{Cu}$ couples is based on the continuous growth of $\mathrm{Cu}_{6} \mathrm{Sn}_{5}$ via soldering and on the formation and growth of $\mathrm{Cu}_{3} \mathrm{Sn}$ between $\mathrm{Cu}_{6} \mathrm{Sn}_{5}$ and $\mathrm{Cu}$. The formation of $\mathrm{Cu}_{3} \mathrm{Sn}$ is governed by the phase stability according to the following reaction [29]:

$$
\mathrm{Cu}_{6} \mathrm{Sn}_{5}+9 \mathrm{Cu} \longrightarrow 5 \mathrm{Cu}_{3} \mathrm{Sn}
$$

Vianco [53] found the formation of $\mathrm{Cu}_{6} \mathrm{Sn}_{5}$ and $\mathrm{Cu}_{3} \mathrm{Sn}$ at the interface between $\mathrm{Cu}$ and $95.5 \mathrm{Sn}-3.9 \mathrm{Ag}-0.6 \mathrm{Cu}$. The author concluded that $\mathrm{Cu}_{6} \mathrm{Sn}_{5}$ layer was formed during soldering and $\mathrm{Cu}_{3} \mathrm{Sn}$ forms during solid state ageing between $\mathrm{Cu}_{6} \mathrm{Sn}_{5}$ and $\mathrm{Cu}$ substrate. The layer growth is diffusion limited and sensitive to the CU concentration in the solder.

The remaining amount of components, which are involved in the interfacial reaction, takes part in phase evolution after the formation of the first phase. In the Sn$\mathrm{Pb} / \mathrm{Cu}$ system, the $\mathrm{Cu}_{6} \mathrm{Sn}_{5}$ layer that first formed transforms into $\mathrm{Cu}_{3} \mathrm{Sn}$ if the solder volume is very small compared with 


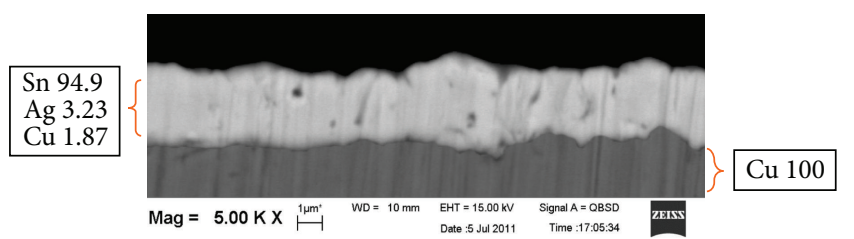

(a)

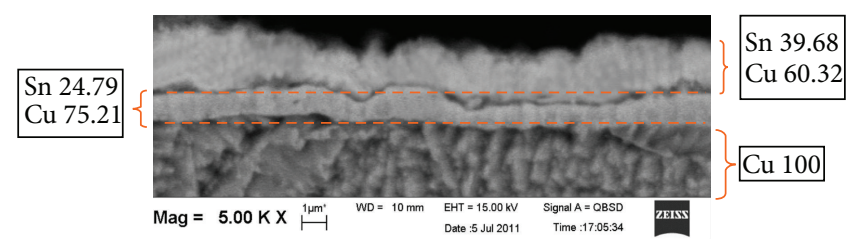

(b)

FIGURE 7: FESEM micrographs of the cross-sectional surface of (a) as-deposited SAC305 thin film and (b) as-reflowed SAC305/Cu at $230^{\circ} \mathrm{C}$ for $30 \mathrm{~s}$.

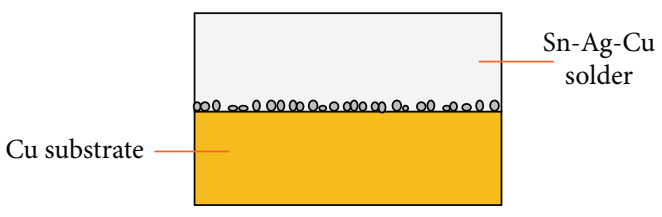

(a)

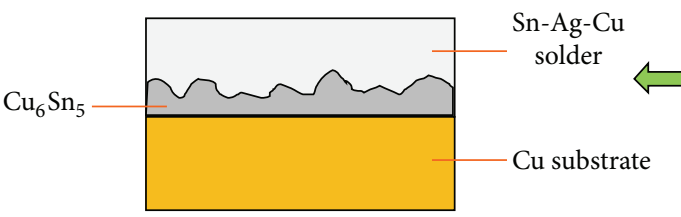

(d)

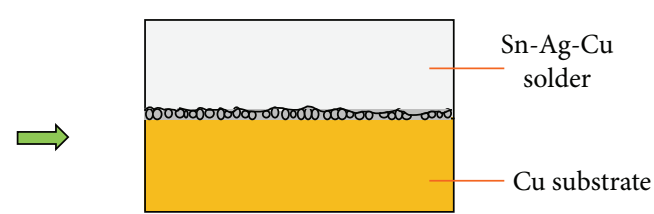

(b)

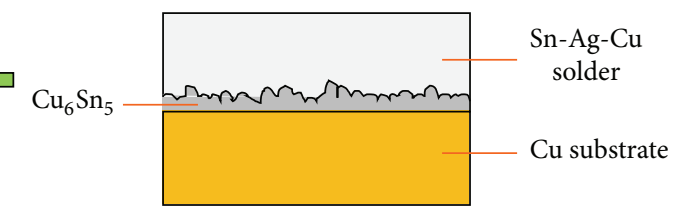

(c)

FIGURE 8: Schematic diagram of the growth mechanism of $\mathrm{Cu}_{6} \mathrm{Sn}_{5}$ at the $\mathrm{Sn}-\mathrm{Ag}$-Cu/Cu interface: (a) individual $\mathrm{Cu}_{6} \mathrm{Sn}_{5}$ grains at the interface, (b) $\mathrm{Cu}_{6} \mathrm{Sn}_{5}$ growth along the interface, (c) the ripening process resulted in scallop $\mathrm{Cu}_{6} \mathrm{Sn}_{5}$, and (d) coarsening of scallop $\mathrm{Cu}_{6} \mathrm{Sn}_{5}$.

that of $\mathrm{Cu}[54,55]$. Conversely, the $\mathrm{Cu}_{3} \mathrm{Sn}$ converts back to $\mathrm{Cu}_{6} \mathrm{Sn}_{5}$ if the thin film is $\mathrm{Cu}$ [56]. $\mathrm{Cu}_{3} \mathrm{Sn}$ could dissolve itself to produce $\mathrm{Cu}_{6} \mathrm{Sn}_{5}$, and it also could react with $\mathrm{Sn}$ atoms to form $\mathrm{Cu}_{6} \mathrm{Sn}_{5}[3,57]$. The transformation equations from $\mathrm{Cu}_{3} \mathrm{Sn}$ to $\mathrm{Cu}_{6} \mathrm{Sn}_{5}$ are shown as follows:

$$
\begin{aligned}
& 5 \mathrm{Cu}_{3} \mathrm{Sn} \longrightarrow 9 \mathrm{Cu}+\mathrm{Cu}_{6} \mathrm{Sn}_{5} \\
& 2 \mathrm{Cu}_{3} \mathrm{Sn}+3 \mathrm{Sn} \longrightarrow \mathrm{Cu}_{6} \mathrm{Sn}_{5}
\end{aligned}
$$

During cooling, the outer layer of $\mathrm{Cu}_{3} \mathrm{Sn}$ that is in contact with the molten solder transforms back to $\mathrm{Cu}_{6} \mathrm{Sn}_{5}$ by the peritectic reaction

$$
\mathrm{L}+\mathrm{Cu}_{3} \mathrm{Sn} \longrightarrow \mathrm{Cu}_{6} \mathrm{Sn}_{5}
$$

Many models exist to forecast the first phase formation of solid state interfacial reactions in thin films. The kinetics of growth of each layer can be diffusion or interfacial reaction controlled. The largest product of the Gibbs free energy change and the rate of growth determines the formation of the first phase. In other words, the phase that has the largest flux of interdiffusion becomes the first phase that is formed.

The difference in IMC growth rates is attributed to various growth kinetics [58]. Diffusion rates control the IMC growth rate, whereas different solder/IMC interface energies control the coarsening of the IMC grains and nucleation kinetics. The IMC growth in solder joints is considered to be an ordinary diffusion growth and should be controlled by interdiffusion of elements of the substrates and of the solder. Interfacial IMCs layers continue to grow even at room temperature after the solder joints have completed solidification because of its low activation energy $[59,60]$.

If the IMC layer growth is a diffusion dominant process, the isothermal growth of the IMC layer should follow the square root time law. The thickness $(d)$ of an IMC layer is directly observed with FESEM together with the help of a image processing system and can be expressed by parabolic equation [61]

$$
d=d_{0}+\sqrt{k t},
$$

where $d_{0}$ is the initial thickness $(\mathrm{cm}), t$ is the aging time (s), and $k$ is the growth rate constant which is strongly related to the diffusion coefficient of atomic elements of the IMC $\left(\mathrm{cm}^{2} / \mathrm{s}\right)$ and can be obtained from the linear regression line.

Rewrite (5) for experimental and plotting purposes as

$$
d-d_{0}=k^{1 / 2} t^{1 / 2} .
$$

The value of $k$ for a particular temperature can be obtained from the slope of the linear regression of the average measured intermetallic thickness $\left(d-d_{0}\right)$ versus $t^{1 / 2}$ plot.

Meanwhile, the activation energies for the intermetallic growth can be calculated using the Arrhenius relationship [43]:

$$
k=k_{o} \exp \left(-\frac{Q}{R T}\right) .
$$


Rewrite (7) for plotting as

$$
\ln k=\ln k_{o}-\frac{Q}{R T}
$$

where $k_{o}$ is the layer-growth constant $\left(\mathrm{cm}^{2} / \mathrm{s}\right), Q$ is the activation energy for layer growth $(\mathrm{kJ} / \mathrm{mol}), R$ is the ideal gas constant $(8.314 \mathrm{~J} / \mathrm{mol} \mathrm{K})$, and $T$ is the absolute temperature (K). The $Q$ for layer growth will be obtained from the slope of the $\ln k$ versus $1 / T$ plot multiplied by $R$.

\section{Effects of Reflow Temperature and Time on Interfacial IMCs}

The thicknesses of the IMC layers are measured at multiple selected areas and then divided by the number of selected points to obtain the average value, as illustrated in Figure 9. The thickness of the IMC layers formed at the SAC305/Cu interface increases with increasing soldering temperature and time. Cu-Sn IMCs were formed at the interface of $\mathrm{Sn}-0.3 \mathrm{Ag}-0.7 \mathrm{Cu}$ and the $\mathrm{Cu}$ substrate by dip soldering in various soldering temperature and time [62]. Either $\mathrm{Cu}_{3} \mathrm{Sn}$ or $\mathrm{Cu}_{6} \mathrm{Sn}_{5}$ intermetallic phase was found at the interfacial zone depending on the soldering condition. The authors concluded that the increase in intermetallic layer thickness in both cases is attributed to the diffusion growth of these intermetallic phases during the soldering process.

Additionally, Yu et al. [61] studied the formation and growth of IMC layer at the interface between Sn-3.5Ag leadfree solder and the $\mathrm{Cu}$ substrate during soldering and aging. The soldering was conducted at $250^{\circ} \mathrm{C}$ using dipping method. A continuous IMC layer was formed in a short time, and the dissolution of the IMC played an important role on the IMC growth. With the increasing of soldering time, both the growth rate and dissolution rate decreased. During aging at 70,125 , and $170^{\circ} \mathrm{C}$ up to $1000 \mathrm{~h}$, the initial scallop morphology of the IMC layer changed to that of a more planar type.

The increase in IMC thickness that resulted from increasing soldering time has also been reported by Yu and Wang [3]. The authors soldered Sn-3.5Ag, Sn-3.5Ag-0.7Cu, Sn-3.5Ag$1.7 \mathrm{Cu}$, and $\mathrm{Sn}-0.5 \mathrm{Ag}-4.0 \mathrm{Cu}$ lead-free solder alloys with a $\mathrm{Cu}$ substrate at $250^{\circ} \mathrm{C}$. The growth of the IMC layers is fast at a short soldering time. The thickness of the IMC layer gradually increases with increasing soldering time. However, the increasing rate of IMC thickness slows down when the soldering time exceeds $60 \mathrm{~s}$. Thus, the authors concluded that the formation of IMC is initially controlled by reaction diffusion and by a high growth rate. After a specific thickness is reached, the growth is controlled by grain boundary diffusion mechanism. Hence, the growth of the IMC layer becomes slow, as shown in Figure 10.

The authors also concluded that $\mathrm{Sn}-0.5 \mathrm{Ag}-4.0 \mathrm{Cu}$ had the thinnest IMC layer when the soldering time is shorter than $90 \mathrm{~s}$. After soldering for $600 \mathrm{~s}$, the order of IMC thickness at the solder joints is $\mathrm{Sn}-3.5 \mathrm{Ag}<\mathrm{Sn}-3.5 \mathrm{Ag}-0.7 \mathrm{Cu}<\mathrm{Sn}-3.5 \mathrm{Ag}-$ $1.7 \mathrm{Cu}<\mathrm{Sn}-0.5 \mathrm{Ag}-4.0 \mathrm{Cu}$. Thus, the IMC thickness increased with increasing $\mathrm{Cu}$ content in the solder alloy. Moreover, the IMCs layer thickness quickly increased with increasing soldering time because of the precipitation effect of the

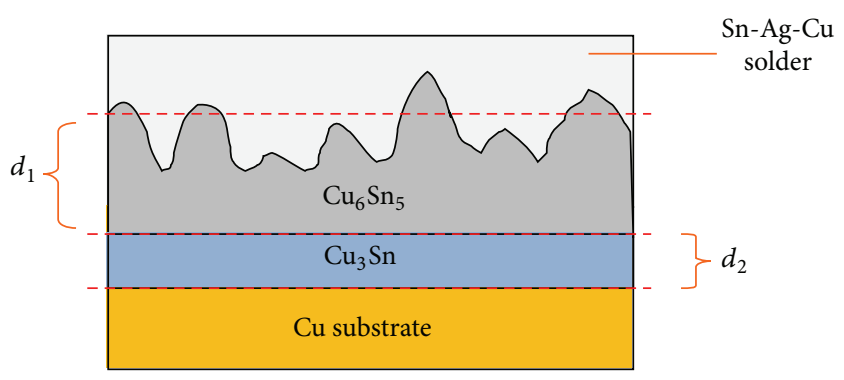

FIGURE 9: Schematic diagram of IMCs thickness measurements, with $d_{1}$ as the thickness of $\mathrm{Cu}_{6} \mathrm{Sn}_{5}$ and $d_{2}$ as the thickness of $\mathrm{Cu}_{3} \mathrm{Sn}$.

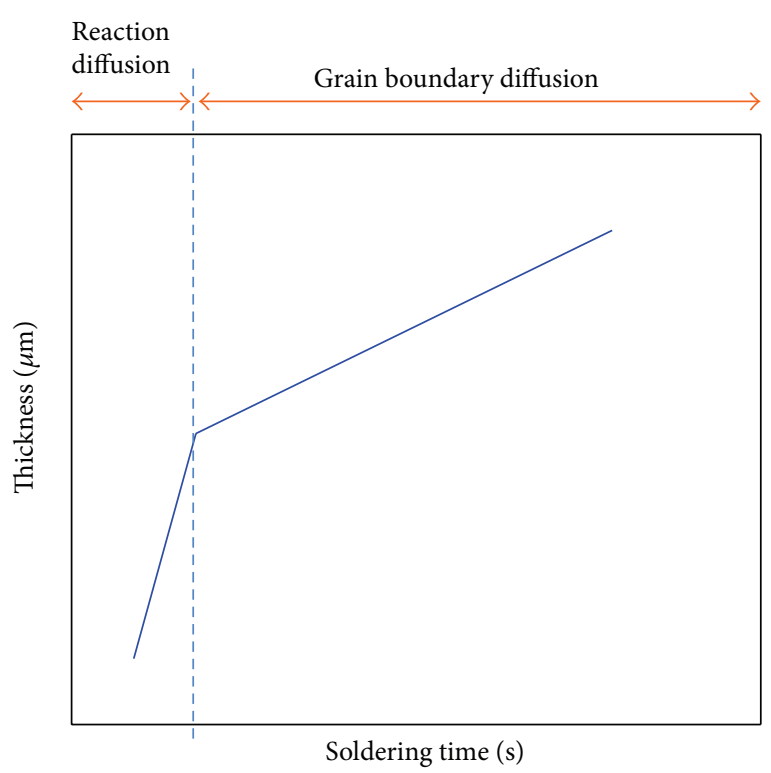

FIGURE 10: Growth mechanisms of IMC layer during soldering process.

$\mathrm{Cu}_{6} \mathrm{Sn}_{5}$ in the liquid solder. Both the $\mathrm{Ag}_{3} \mathrm{Sn}$ phase and $\mathrm{Cu}_{6} \mathrm{Sn}_{5}$ compounds were detected in the solder matrix of Sn-Ag$\mathrm{Cu} / \mathrm{Cu}$ after soldering for $30 \mathrm{~s}$. The $\mathrm{Cu}_{6} \mathrm{Sn}_{5}$ became coarser with increasing $\mathrm{Cu}$ content.

After prolonged soldering for $180 \mathrm{~s}$, a thin $\mathrm{Cu}_{3} \mathrm{Sn}$ layer was formed between the $\mathrm{Cu}_{6} \mathrm{Sn}_{5}$ layer and $\mathrm{Cu}$. Moreover, the IMC layers became thicker, and the number of the IMC grains decreased when the samples underwent soldering for $600 \mathrm{~s}$, which resulted in a scallop-like morphology.

Figure 11 demonstrates the growth of $\mathrm{Cu}-\mathrm{Sn}$ IMCs at varying reflow times. Figure 11(a) shows the formation of a scallop-type structure at the interfacial layer of SAC305/Cu when the reflow time was $30 \mathrm{~s}$. $\mathrm{Ag}_{3} \mathrm{Sn}$ are present in the solder matrix. Furthermore, spalling of $\mathrm{Cu}_{6} \mathrm{Sn}_{5}$ spheroids was observed because the Sn concentration in SAC305 was high. The formation of the spheroids was assisted by the ripening reaction among the compound grains. When soldered for $180 \mathrm{~s}$, a thin band of $\mathrm{Cu}_{3} \mathrm{Sn}$ were observed at the $\mathrm{Cu}_{6} \mathrm{Sn}_{5} / \mathrm{Cu}$ interface (Figure 11(b)). When soldered for $600 \mathrm{~s}$, the IMC layers became thicker, and the number of scallop 


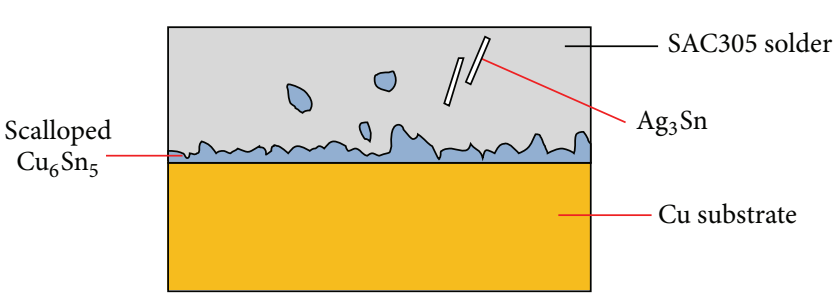

(a) $t<30 \mathrm{~s}$

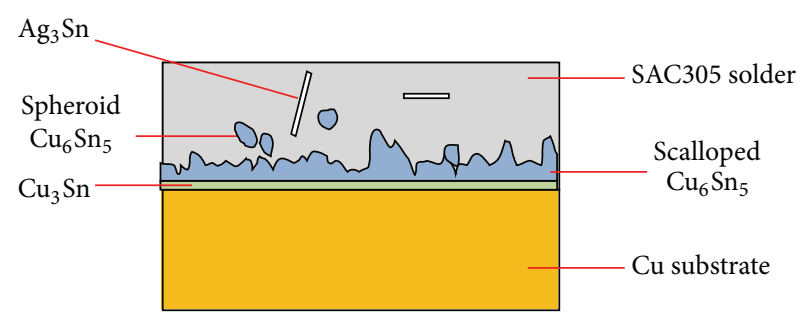

(b) $30 \mathrm{~s}<t<180 \mathrm{~s}$

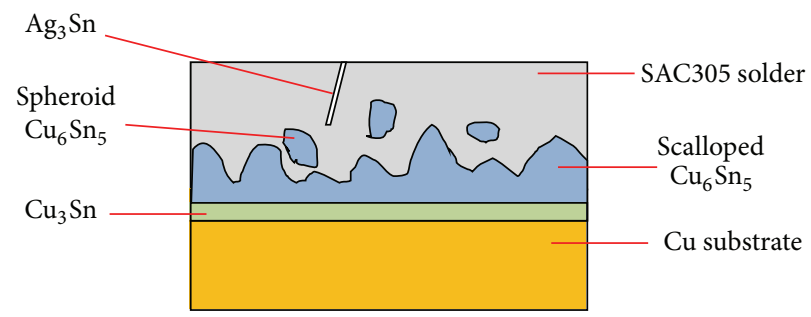

(c) $180 \mathrm{~s}<t<600 \mathrm{~s}$

FIGURE 11: Growth mechanism of Cu-Sn IMCs at various reflow times: (a) formation of scallop $\mathrm{Cu}_{6} \mathrm{Sn}_{5}$ at the SAC305/Cu interfacial region, (b) appearance of $\mathrm{Cu}_{3} \mathrm{Sn}$ between the $\mathrm{Cu}_{6} \mathrm{Sn}_{5} / \mathrm{Cu}$ interface, and (c) increase in both $\mathrm{Cu}$-Sn IMCs thicknesses with increasing reflow times.

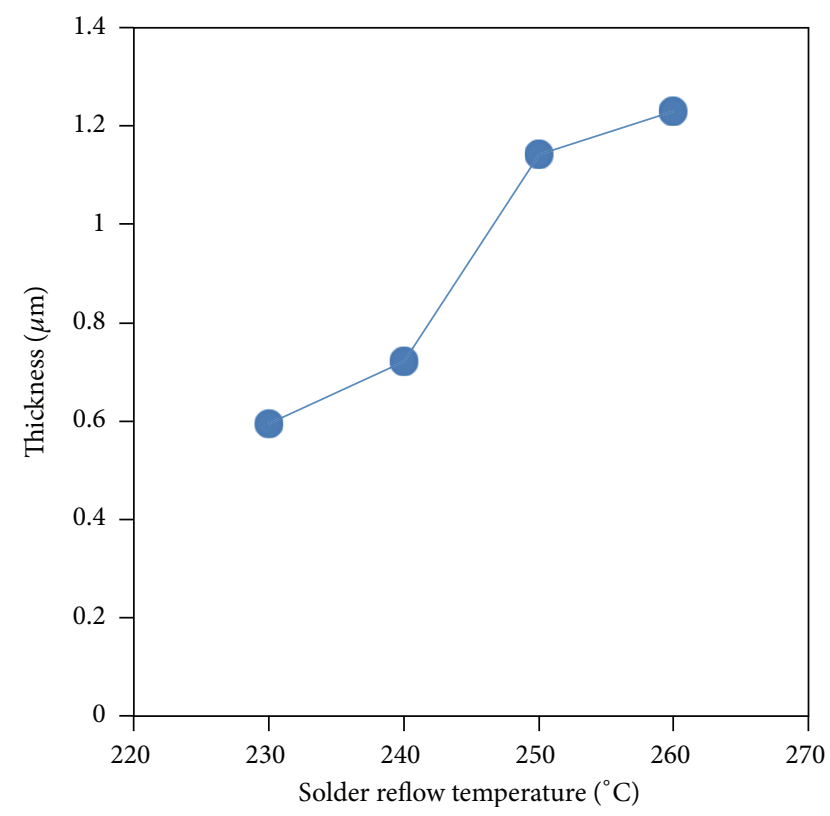

(a)

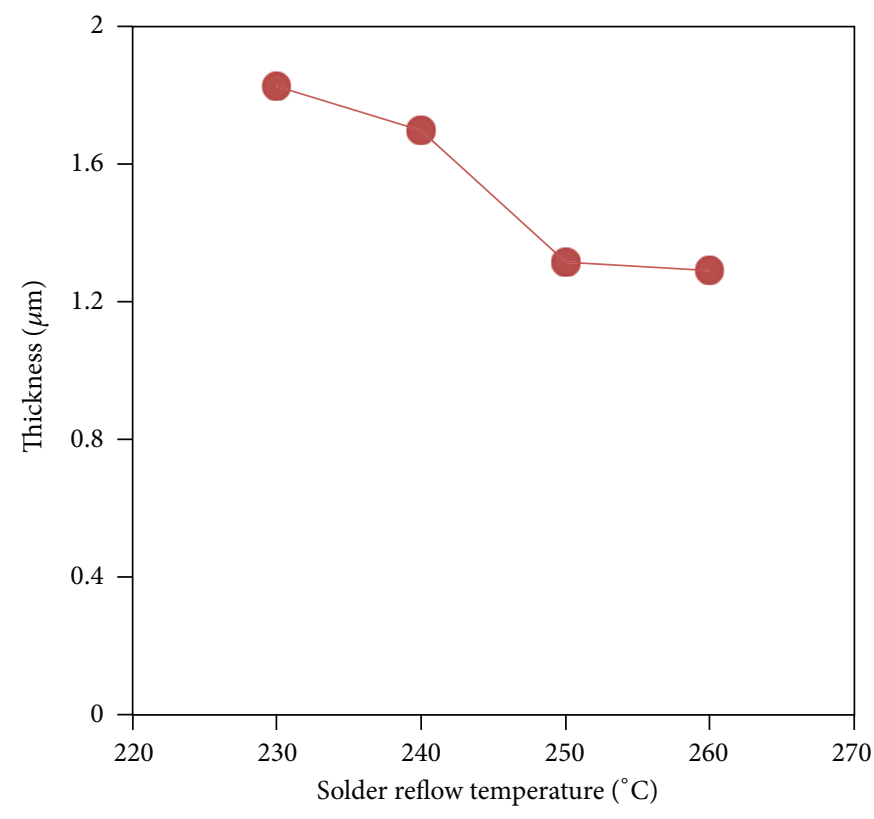

(b)

FIGURE 12: (a) $\mathrm{Cu}_{3} \mathrm{Sn}$ and (b) $\mathrm{Cu}_{6} \mathrm{Sn}_{5}$ IMCs thickness as a function of reflow temperature at a reflow time of $30 \mathrm{~s}$.

$\mathrm{Cu}_{6} \mathrm{Sn}_{5}$ decreased. $\mathrm{Cu}_{3} \mathrm{Sn}$ maintained its continuous layerlike morphology with increasing thickness and reflow time (Figure 11(c)).

$\mathrm{Li}$ and Chen [63] also conducted an experiment on commercial lead-free solders, namely, Sn-3.5Ag and Sn$3.5 \mathrm{Ag}-0.7 \mathrm{Cu}$, by using a standard infrared reflow oven at $250^{\circ} \mathrm{C}$ for $2,6,15,30,60,120,240$, and 360 s. Both $\mathrm{Cu}_{6} \mathrm{Sn}_{5}$ and $\mathrm{Ag}_{3} \mathrm{Sn}$ were detected in the solder joint. The $\mathrm{Ag}_{3} \mathrm{Sn}$ phase was detected because it was formed on top of the layer during the reflow process. However, a scallop-like layer of $\mathrm{Cu}_{6} \mathrm{Sn}_{5}$ IMC was located at the solder-Cu substrate interface. The authors added that $\mathrm{Cu}_{3} \mathrm{Sn}$ phase was not observed in the as-solidified solder joint, although it may exist between $\mathrm{Cu}$ and the $\mathrm{Cu}_{6} \mathrm{Sn}_{5}$ phase.

Figure 12 compares the thicknesses of the IMC layers formed at the interfacial region as a function of reflow temperatures. The $\mathrm{Cu}_{3} \mathrm{Sn}$ intermetallic layer consistently increased with increasing temperature (Figure 12(a)), whereas $\mathrm{Cu}_{6} \mathrm{Sn}_{5}$ gradually decreased with increasing reflow temperature (Figure 12(b)). Figure 13 shows the relationship between the IMC layer thickness and the reflow time. Likewise, at a specific soldering temperature, the thickness 


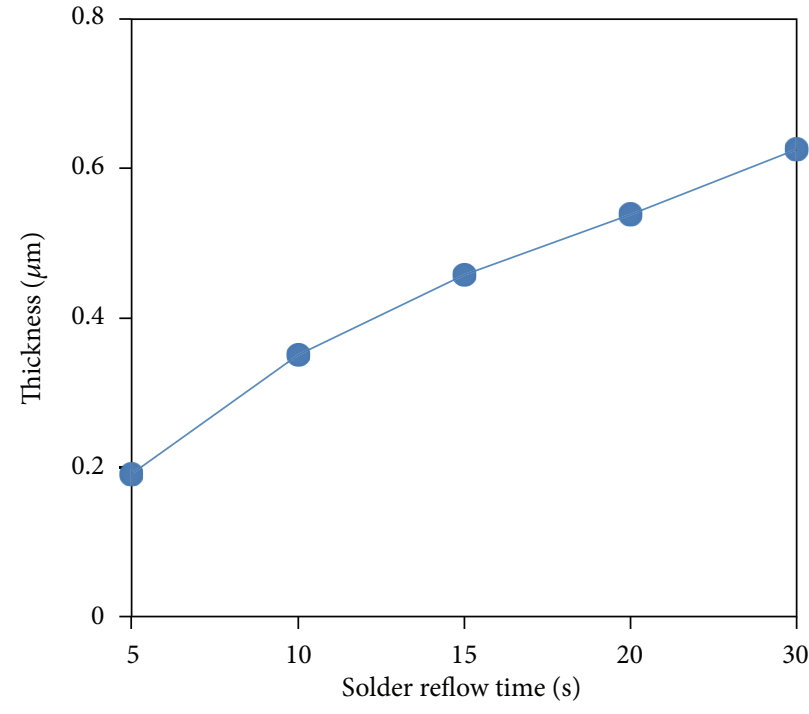

(a)

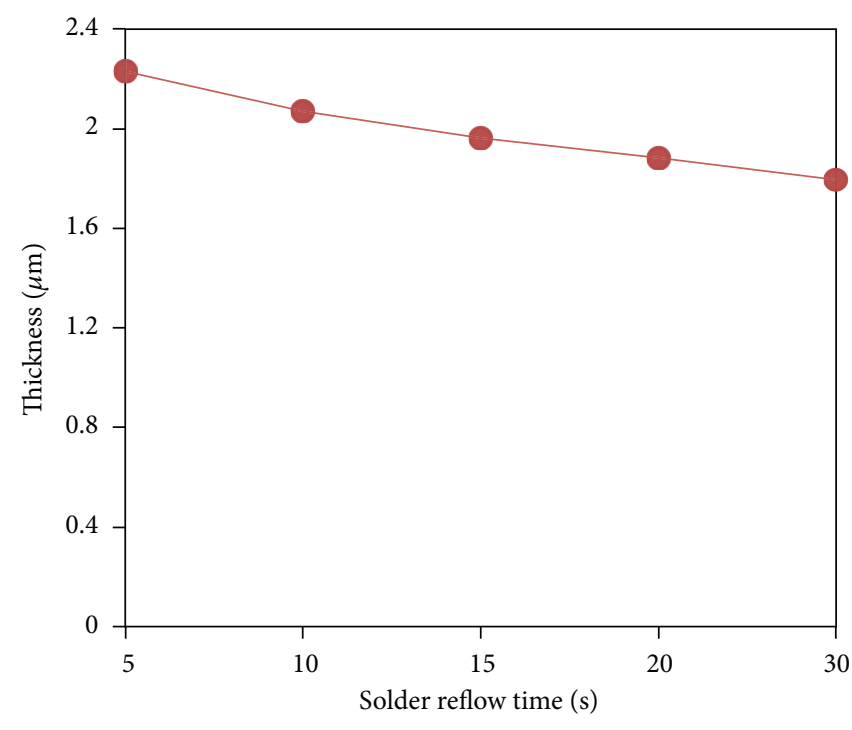

(b)

Figure 13: (a) $\mathrm{Cu}_{3} \mathrm{Sn}$ and (b) $\mathrm{Cu}_{6} \mathrm{Sn}_{5}$ IMC layer thickness versus reflow time at $230^{\circ} \mathrm{C}$.

of the IMC layers at the interfacial zone increased with increasing soldering time. Based on the study done by $\mathrm{Yu}$ and Wang [3], the increase in soldering time enables the IMC layer to grow quickly because of the precipitation effect of $\mathrm{Cu}_{6} \mathrm{Sn}_{5} \cdot \mathrm{Cu}_{6} \mathrm{Sn}_{5}$ could be recalled to develop into $\mathrm{Cu}_{3} \mathrm{Sn}$ when the $\mathrm{Sn}$ supply is limited. Hence, the $\mathrm{Cu}_{3} \mathrm{Sn}$ thickness increases with decreasing $\mathrm{Cu}_{6} \mathrm{Sn}_{5}$ thickness despite the fact that $\mathrm{Cu}_{6} \mathrm{Sn}_{5}$ generally grows with increasing solder time. These results provide evidence that the interfacial $\mathrm{Cu}_{3} \mathrm{Sn}$ layer grows at the expense of $\mathrm{Cu}_{6} \mathrm{Sn}_{5}$ according to the reaction $\mathrm{Cu}_{6} \mathrm{Sn}_{5}+9 \mathrm{Cu} \rightarrow 5 \mathrm{Cu}_{3} \mathrm{Sn}$ [29]. Moreover, the $\mathrm{Cu}_{3} \mathrm{Sn}$ thickness growth follows a linear equation. According to material kinetics, a linear growth indicates that the formation of the interfacial $\mathrm{Cu}$-Sn IMC layer is an interfacial reaction-controlled process [64].

The increase in the $\mathrm{Cu}_{3} \mathrm{Sn}$ IMC layer results from the diffusion and reaction type growth during the soldering process [17]. The growth of $\mathrm{Cu}_{3} \mathrm{Sn}$ consists of several steps: the dissolution of $\mathrm{Cu}$ from the $\mathrm{Cu}$ pad, the diffusion of $\mathrm{Cu}$ and $\mathrm{Sn}$ through the existing $\mathrm{Cu}_{3} \mathrm{Sn}$ layer, and the conversion of $\mathrm{Cu}_{6} \mathrm{Sn}_{5}$ into $\mathrm{Cu}_{3} \mathrm{Sn}$ at the $\mathrm{Cu}_{6} \mathrm{Sn}_{5} / \mathrm{Cu}_{3} \mathrm{Sn}$ interface and the reaction of $\mathrm{Sn}$ with $\mathrm{Cu}$ at the $\mathrm{Cu} / \mathrm{Cu}_{3} \mathrm{Sn}$ interface [65]. Conversely, $\mathrm{Cu}_{6} \mathrm{Sn}_{5}$ is formed by the dissolution of $\mathrm{Cu}$, followed by a chemical reaction [17], and its growth is restricted by the $\mathrm{Cu}_{3} \mathrm{Sn}$ layer because the amount of free $\mathrm{Cu}$ atoms that can diffuse to the $\mathrm{Cu}_{6} \mathrm{Sn}_{5}$ is very small. Therefore, $\mathrm{Cu}_{3} \mathrm{Sn}$ grows rapidly with temperature, consuming $\mathrm{Cu}_{6} \mathrm{Sn}_{5}$ at the interface of $\mathrm{Cu}_{3} \mathrm{Sn} / \mathrm{Cu}_{6} \mathrm{Sn}_{5}$.

\section{Conclusions}

$\mathrm{Sn}-\mathrm{Ag}-\mathrm{Cu}$ is the leading candidate for the fabrication of ecofriendly products. Two intermetallic layers are commonly found at the interfacial zone of $\mathrm{Sn}-\mathrm{Ag}-\mathrm{Cu}$ and the $\mathrm{Cu}$ substrate, that is, $\mathrm{Cu}_{6} \mathrm{Sn}_{5}$ and $\mathrm{Cu}_{3} \mathrm{Sn}$. $\mathrm{Cu}_{6} \mathrm{Sn}_{5}$ forms first and possesses a scallop-like structure, whereas $\mathrm{Cu}_{3} \mathrm{Sn}$ emerges at the $\mathrm{Cu}_{6} \mathrm{Sn}_{5} / \mathrm{Cu}$ interface and has a layered structure. However, the thickness of $\mathrm{Cu}_{3} \mathrm{Sn}$ is much smaller than that of $\mathrm{Cu}_{6} \mathrm{Sn}_{5}$, and its formation requires longer contact times. Morphological transformations could occur depending on the phase stability. Both $\mathrm{Cu}-\mathrm{Sn}$ IMCs grow with increasing reflow temperature and time.

\section{Acknowledgments}

L. M. Lee would like to thank MyBrain15 and the USM Fellowship Scheme for the financial assistance. A. A. Mohamad gratefully acknowledges the financial support of USM (RUI Grant no. 814112).

\section{References}

[1] K. S. Kim, S. H. Huh, and K. Suganuma, "Effects of intermetallic compounds on properties of $\mathrm{Sn}-\mathrm{Ag}-\mathrm{Cu}$ lead-free soldered joints," Journal of Alloys and Compounds, vol. 352, no. 1-2, pp. 226-236, 2003.

[2] J.-W. Yoon, S.-W. Kim, and S.-B. Jung, "IMC morphology, interfacial reaction and joint reliability of $\mathrm{Pb}$-free $\mathrm{Sn}-\mathrm{Ag}-\mathrm{Cu}$ solder on electrolytic Ni BGA substrate," Journal of Alloys and Compounds, vol. 392, no. 1-2, pp. 247-252, 2005.

[3] D. Q. Yu and L. Wang, "The growth and roughness evolution of intermetallic compounds of $\mathrm{Sn}-\mathrm{Ag}-\mathrm{Cu} / \mathrm{Cu}$ interface during soldering reaction," Journal of Alloys and Compounds, vol. 458, no. 1-2, pp. 542-547, 2008.

[4] M. Farooq, S. Ray, A. Sarkhel, and C. Goldsmith, "Evaluation of lead $(\mathrm{Pb})$-free ceramic ball grid array (CBGA): wettability, microstructure and reliability," in 51st Electronic Components and Technology Conference, pp. 978-986, usa, June 2001.

[5] S. K. Kang, D. Leonard, D. A. Y. Shih et al., "Interfacial reactions of Sn-Ag-Cu solders modified by minor Zn alloying addition," Journal of Electronic Materials, vol. 35, no. 3, pp. 479-485, 2006. 
[6] H. H. Manko, Book Solders and Soldering: Materials, Design, Production, and Analysis for Reliable Bonding, McGraw-Hill, New York, NY, USA, 2001.

[7] C. M. L. Wu, D. Q. Yu, C. M. T. Law, and L. Wang, "Properties of lead-free solder alloys with rare earth element additions," Materials Science and Engineering $R$, vol. 44, no. 1, pp. 1-44, 2004.

[8] K. N. Subramanian, Book Lead-Free Electronic Solders: A Special Issue of the Journal of Materials Science: Materials in Electronics, Springer, 2007.

[9] C. H. Wang and S. W. Chen, "Sn-0.7 wt.\%Cu/Ni interfacial reactions at $250^{\circ}$ C," Acta Materialia, vol. 54, no. 1, pp. 247-253, 2006.

[10] D. Li, C. Liu, and P. P. Conway, "Characteristics of intermetallics and micromechanical properties during thermal ageing of Sn$\mathrm{Ag-Cu}$ flip-chip solder interconnects," Materials Science and Engineering A, vol. 391, no. 1-2, pp. 95-103, 2005.

[11] Y. C. Chan and D. Yang, "Failure mechanisms of solder interconnects under current stressing in advanced electronic packages," Progress in Materials Science, vol. 55, no. 5, pp. 428475, 2010.

[12] Y. Li-Lei, L. Zonghe, J. Liu, and A. Tholen, "Microstructural coarsening of lead free solder joints during thermal cycling," in Proceedings of the 50th Electronic Components \& Technology Conference, pp. 134-137, 2000.

[13] A. K. Gain, T. Fouzder, Y. C. Chan, A. Sharif, N. B. Wong, and W. K. C. Yung, "The influence of addition of Al nano-particles on the microstructure and shear strength of eutectic Sn-Ag$\mathrm{Cu}$ solder on $\mathrm{Au} / \mathrm{Ni}$ metallized Cu pads," Journal of Alloys and Compounds, vol. 506, no. 1, pp. 216-223, 2010.

[14] H. H. Manko, Book Solder and Soldering, McGraw-Hill, New York, NY, USA, 1979.

[15] R. J. K. Wassink, Book Soldering in Electronics, Electrochemical Publications, Isle of Man, UK, 1989.

[16] M. Abtew and G. Selvaduray, "Lead-free solders in microelectronics," Materials Science and Engineering R, vol. 27, no. 5, pp. 95-141, 2000.

[17] T. Laurila, V. Vuorinen, and J. K. Kivilahti, "Interfacial reactions between lead-free solders and common base materials," Materials Science and Engineering R, vol. 49, no. 1-2, pp. 1-60, 2005.

[18] D. R. Frear, Book Solder Mechanics: A states of the Art Assessment, Minerals, Metals \& Materials Society, Warrendale, $\mathrm{Pa}$, USA, 1991.

[19] L. M. Lee, H. Haliman, and A. A. Mohamad, "Interfacial reaction of a $\mathrm{Sn}-3.0 \mathrm{Ag}-0.5 \mathrm{Cu}$ thin film during solder reflow," Soldering \& Surface Mount Technology, vol. 25, no. 1, pp. 15-23, 2013.

[20] M. C. Liew, I. Ahmad, L. M. Lee, M. F. M. Nazeri, H. Haliman, and A. A. Mohamad, "Corrosion behavior of Sn-3.0Ag- $0.5 \mathrm{Cu}$ lead-free solder in potassium hydroxide electrolyte," Metallurgical and Materials Transactions A, vol. 43, no. 10, pp. 3742-3747, 2012.

[21] C. Lea, Book a Scientific Guide to Surface Mount Technology, Electrochemical Publications, Ayrshire, Scotland, 1988.

[22] S. W. Chen, C. H. Wang, S. K. Lin, and C. N. Chiu, "Phase diagrams of $\mathrm{Pb}$-free solders and their related materials systems," Journal of Materials Science, vol. 18, no. 1-3, pp. 19-37, 2007.

[23] S. M. L. Nai, J. Wei, and M. Gupta, "Interfacial intermetallic growth and shear strength of lead-free composite solder joints," Journal of Alloys and Compounds, vol. 473, no. 1-2, pp. 100-106, 2009.
[24] J. K. Kivilahti, "The chemical modeling of electronic materials and interconnections," JOM, vol. 54, no. 12, pp. 52-57, 2002.

[25] M. J. Rizvi, Y. C. Chan, C. Bailey, H. Lu, and M. N. Islam, "Effect of adding $1 \mathrm{wt} \% \mathrm{Bi}$ into the $\mathrm{Sn}-2.8 \mathrm{Ag}-0.5 \mathrm{Cu}$ solder alloy on the intermetallic formations with $\mathrm{Cu}$-substrate during soldering and isothermal aging," Journal of Alloys and Compounds, vol. 407, no. 1-2, pp. 208-214, 2006.

[26] X. Liu, M. Huang, Y. Zhao, C. M. L. Wu, and L. Wang, “The adsorption of $\mathrm{Ag} 3 \mathrm{Sn}$ nano-particles on $\mathrm{Cu}-\mathrm{Sn}$ intermetallic compounds of $\mathrm{Sn}-3 \mathrm{Ag}-0.5 \mathrm{Cu} / \mathrm{Cu}$ during soldering," Journal of Alloys and Compounds, vol. 492, no. 1-2, pp. 433-438, 2010.

[27] F.-J. Wang, Z.-S. Yu, and K. Qi, "Intermetallic compound formation at $\mathrm{Sn}-3.0 \mathrm{Ag}-0.5 \mathrm{Cu}-1.0 \mathrm{Zn}$ lead-free solder alloy/Cu interface during as-soldered and as-aged conditions," Journal of Alloys and Compounds, vol. 438, no. 1-2, pp. 110-115, 2007.

[28] A. Kar, M. Ghosh, A. K. Ray, and R. N. Ghosh, "Effect of copper addition on the microstructure and mechanical properties of lead free solder alloy," Materials Science and Engineering A, vol. 459, no. 1-2, pp. 69-74, 2007.

[29] F. Gao, T. Takemoto, and H. Nishikawa, "Effects of Co and $\mathrm{Ni}$ addition on reactive diffusion between $\mathrm{Sn}-3.5 \mathrm{Ag}$ solder and $\mathrm{Cu}$ during soldering and annealing," Materials Science and Engineering A, vol. 420, no. 1-2, pp. 39-46, 2006.

[30] J.-W. Yoon, B.-I. Noh, B.-K. Kim, C.-C. Shur, and S.-B. Jung, "Wettability and interfacial reactions of $\mathrm{Sn}-\mathrm{Ag}-\mathrm{Cu} / \mathrm{Cu}$ and $\mathrm{Sn}-$ Ag-Ni/Cu solder joints," Journal of Alloys and Compounds, vol. 486, no. 1-2, pp. 142-147, 2009.

[31] J.-W. Yoon and S.-B. Jung, "Effect of surface finish on interfacial reactions of $\mathrm{Cu} / \mathrm{Sn}-\mathrm{Ag}-\mathrm{Cu} / \mathrm{Cu}(\mathrm{ENIG})$ sandwich solder joints," Journal of Alloys and Compounds, vol. 448, no. 1-2, pp. 177-184, 2008.

[32] R. A. Gagliano and M. E. Fine, "Growth of $\eta$ phase scallops and whiskers in liquid tin-solid copper reaction couples," JOM, vol. 53, no. 6, pp. 33-38, 2001.

[33] M. Reid, J. Punch, M. Collins, and C. Ryan, "Effect of Ag content on the microstructure of $\mathrm{Sn}$-Ag-Cu based solder alloys," Soldering and Surface Mount Technology, vol. 20, no. 4, pp. 3-8, 2008.

[34] J. M. Song, J. J. Lin, C. F. Huang, and H. Y. Chuang, "Crystallization, morphology and distribution of Ag3Sn in $\mathrm{Sn}-\mathrm{Ag}-\mathrm{Cu}$ alloys and their influence on the vibration fracture properties," Materials Science and Engineering A, vol. 466, no. 1-2, pp. 9-17, 2007.

[35] K. Zeng and K. N. Tu, "Six cases of reliability study of Pbfree solder joints in electronic packaging technology," Materials Science and Engineering R, vol. 38, no. 2, pp. 55-105, 2002.

[36] C. T. Sims, N. S. Stoloff, and W. C. Hagel, Book Superalloys II, John Wiley \& Sons, New York, NY, USA, 1987.

[37] M. Reid, M. J. Pomeroy, and J. S. Robinson, "Microstructural instability in coated single crystal superalloys," Journal of Materials Processing Technology, vol. 153-154, no. 1-3, pp. 660665, 2004.

[38] H. K. Kim, H. K. Liou, and K. N. Tu, “Three-dimensional morphology of a very rough interface formed in the soldering reaction between eutectic $\mathrm{SnPb}$ and Cu," Applied Physics Letters, vol. 66, no. 16, pp. 2337-2339, 1995.

[39] H. K. Kim and K. N. Tu, "Kinetic analysis of the soldering reaction between eutectic $\mathrm{SnPb}$ alloy and $\mathrm{Cu}$ accompanied by ripening," Physical Review B, vol. 53, no. 23, pp. 16027-16034, 1996. 
[40] A. A. Liu, H. K. Kim, K. N. Tu, and P. A. Totta, "Spalling of $\mathrm{Cu} 6 \mathrm{Sn} 5$ spheroids in the soldering reaction of eutectic $\mathrm{SnPb}$ on $\mathrm{Cr} / \mathrm{Cu} / \mathrm{Au}$ thin films," Journal of Applied Physics, vol. 80, no. 5, pp. 2774-2780, 1996.

[41] S. Bader, W. Gust, and H. Hieber, "Rapid formation of intermetallic compounds interdiffusion in the $\mathrm{CuSn}$ and $\mathrm{NiSn}$ systems," Acta Metallurgica et Materialia, vol. 43, no. 1, pp. 329337, 1995.

[42] S. Choi, J. P. Lucas, K. N. Subramanian, and T. R. Bieler, "Formation and growth of interfacial intermetallic layers in eutectic Sn-Ag solder and its composite solder joints," Journal of Materials Science, vol. 11, no. 6, pp. 497-502, 2000.

[43] P. L. Tu, Y. C. Chan, K. C. Hung, and J. K. L. Lai, "Growth kinetics of intermetallic compounds in chip scale package solder joint," Scripta Materialia, vol. 44, no. 2, pp. 317-323, 2001.

[44] S. K. Kang, R. S. Rai, and S. Purushothaman, "Interfacial reactions during soldering with lead-tin eutectic and lead $(\mathrm{Pb})$ free, tin-rich solders," Journal of Electronic Materials, vol. 25, no. 7, pp. 1113-1120, 1996.

[45] M. Schaefer, R. A. Fournelle, and J. Liang, "Theory for intermetallic phase growth between $\mathrm{Cu}$ and liquid $\mathrm{Sn}-\mathrm{Pb}$ solder based on grain boundary diffusion control," Journal of Electronic Materials, vol. 27, no. 11, pp. 1167-1176, 1998.

[46] C. K. Shin, Y. J. Baik, and J. Y. Huh, "Effects of microstructural evolution and intermetallic layer growth on shear strength of ball-grid-array $\mathrm{Sn}-\mathrm{Cu}$ solder joints," Journal of Electronic Materials, vol. 30, no. 10, pp. 1323-1331, 2001.

[47] M. N. Islam, Y. C. Chan, M. J. Rizvi, and W. Jillek, "Investigations of interfacial reactions of $\mathrm{Sn}-\mathrm{Zn}$ based and $\mathrm{Sn}-\mathrm{Ag}$-Cu lead-free solder alloys as replacement for $\mathrm{Sn}-\mathrm{Pb}$ solder," Journal of Alloys and Compounds, vol. 400, no. 1-2, pp. 136-144, 2005.

[48] B. J. Lee, N. M. Hwang, and H. M. Lee, "Prediction of interface reaction products between $\mathrm{Cu}$ and various solder alloys by thermodynamic calculation," Acta Materialia, vol. 45, no. 5, pp. 1867-1874, 1997.

[49] R. A. Lord and A. Umantsev, "Early stages of soldering reactions," Journal of Applied Physics, vol. 98, no. 6, Article ID 063525, 11 pages, 2005.

[50] J. Görlich, G. Schmitz, and K. N. Tu, "On the mechanism of the binary $\mathrm{Cu} / \mathrm{Sn}$ solder reaction," Applied Physics Letters, vol. 86, no. 5, Article ID 053106, 3 pages, 2005.

[51] S. Choi, T. R. Bieler, J. P. Lucas, and K. N. Subramanian, "Characterization of the growth of intermetallic interfacial layers of $\mathrm{Sn}-\mathrm{Ag}$ and $\mathrm{Sn}-\mathrm{Pb}$ eutectic solders and their composite solders on $\mathrm{Cu}$ substrate during isothermal long-term aging," Journal of Electronic Materials, vol. 28, no. 11, pp. 1209-1215, 1999.

[52] W. K. Choi and H. M. Lee, "Effect of soldering and aging time on interfacial microstructure and growth of intermetallic compounds between Sn-3.5Ag solder alloy and Cu substrate," Journal of Electronic Materials, vol. 29, no. 10, pp. 1207-1213, 2000.

[53] P. T. Vianco, "An overview of surface finishes and their role in printed circuit board solderability and solder joint performance," Circuit World, vol. 25, no. 1, pp. 6-24, 1999.

[54] A. J. Sunwoo, J. W. Morris, and G. K. Lucey, "The growth of $\mathrm{Cu}-\mathrm{Sn}$ intermetallics at a pretinned copper-solder interface," Metallurgical Transactions A, vol. 23, no. 4, pp. 1323-1332, 1992.

[55] H. L. Reynolds and J. W. Morris, "The role of Cu-Sn intermetallics in wettability degradation," Journal of Electronic Materials, vol. 24, no. 10, pp. 1429-1434, 1995.
[56] R. E. Pratt, E. I. Stromswold, and D. J. Quesnel, "Effect of solid-state intermetallic growth on the fracture toughness of $\mathrm{Cu} / 63 \mathrm{Sn}-37 \mathrm{~Pb}$ solder joints," IEEE Transactions on Components Packaging and Manufacturing Technology Part A, vol. 19, no. 1, pp. 134-141, 1996.

[57] A. Paul, The kirkendall effect in solid state diffusion [Ph.D. thesis], Eindhoven University of Technology, 2004.

[58] K. Zeng, "Lead-free soldering: materials science and solder joint reliability," JOM, vol. 61, no. 6, p. 28, 2009.

[59] I. Dutta, P. Kumar, and G. Subbarayan, "Microstructural coarsening in Sn-Ag-based solders and its effects on mechanical properties," JOM, vol. 61, no. 6, pp. 29-38, 2009.

[60] S. W. Chen, C. H. Wang, S. K. Lin, C. N. Chiu, and C. C. Chen, "Phase transformation and microstructural evolution in solder joints," JOM, vol. 59, no. 1, pp. 39-43, 2007.

[61] D. Q. Yu, C. M. L. Wu, C. M. T. Law, L. Wang, and J. K. L. Lai, "Intermetallic compounds growth between $\mathrm{Sn}-3.5 \mathrm{Ag}$ lead-free solder and $\mathrm{Cu}$ substrate by dipping method," Journal of Alloys and Compounds, vol. 392, no. 1-2, pp. 192-199, 2005.

[62] N. Mookam and K. Kanlayasiri, "Effect of soldering condition on formation of intermetallic phases developed between Sn0.3Ag-0.7Cu low-silver lead-free solder and $\mathrm{Cu}$ substrate," Journal of Alloys and Compounds, vol. 509, no. 21, pp. 62766279, 2011.

[63] G. Y. Li and B. L. Chen, "Formation and Growth Kinetics of Interfacial Intermetallics in Pb-Free Solder Joint," IEEE Transactions on Components and Packaging Technologies, vol. 26, no. 3, pp. 651-658, 2003.

[64] A. C. K. So and Y. C. Chan, "Reliability studies of surface mount solder joints-effect of Cu-Sn intermetallic compounds," IEEE Transactions on Components Packaging and Manufacturing Technology Part B, vol. 19, no. 3, pp. 661-668, 1996.

[65] W. Peng, E. Monlevade, and M. E. Marques, "Effect of thermal aging on the interfacial structure of $\mathrm{SnAgCu}$ solder joints on Cu," Microelectronics Reliability, vol. 47, no. 12, pp. 2161-2168, 2007. 

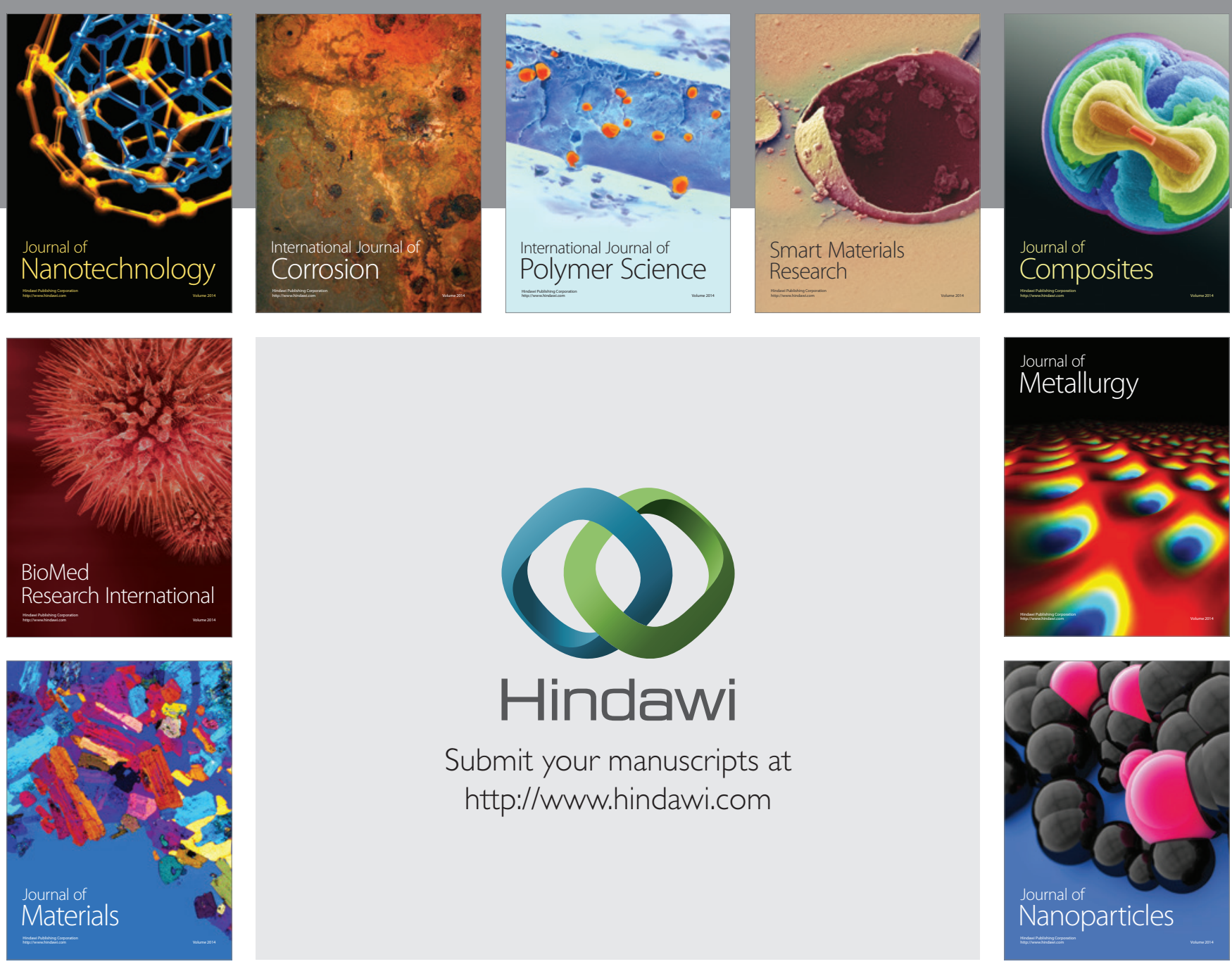

Submit your manuscripts at http://www.hindawi.com
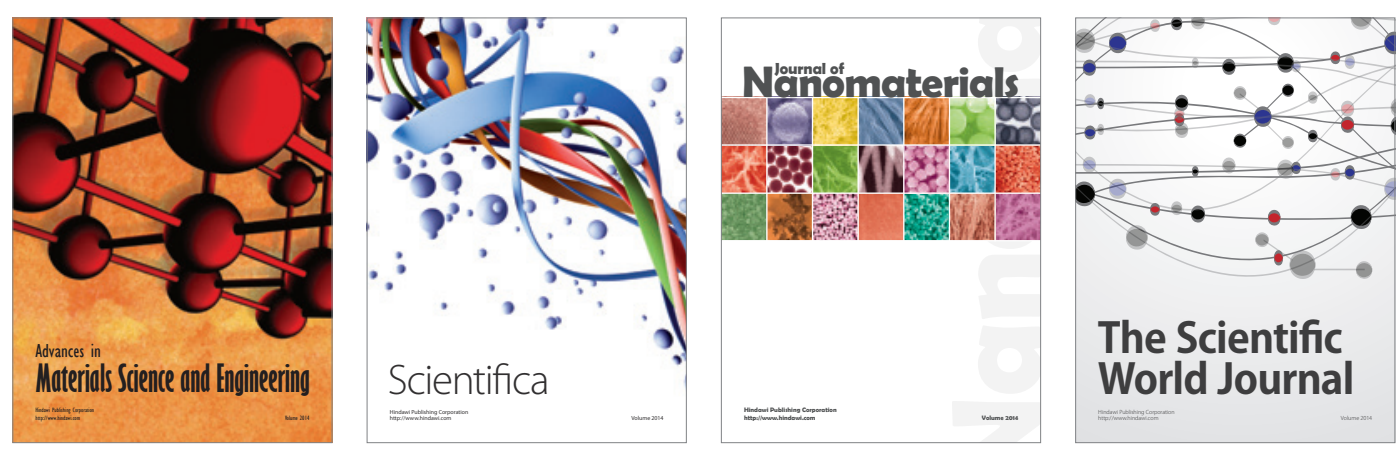

\section{The Scientific World Journal}
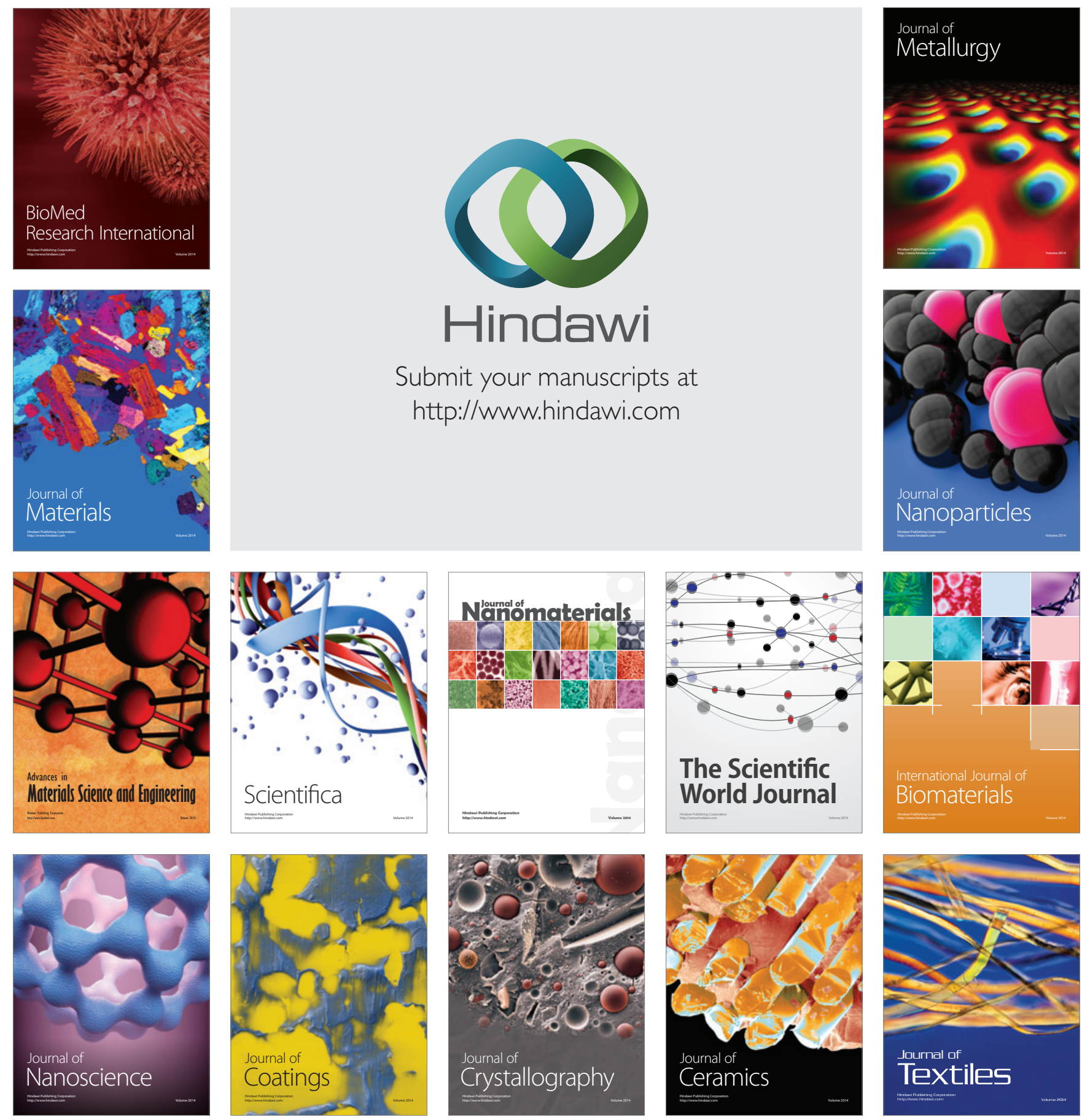